\title{
Effects of a morbillivirus epizootic on long-finned pilot whales Globicephala melas in Spanish Mediterranean waters
}

\author{
Kaja Wierucka ${ }^{1, *}$, Philippe Verborgh ${ }^{1}{ }$ Rossa Meade $^{1}$, Leyla Colmant ${ }^{1}$, \\ Pauline Gauffier ${ }^{1}$, Ruth Esteban ${ }^{1}$, Renaud de Stephanis ${ }^{2}$, Ana Cañadas ${ }^{3}$ \\ ${ }^{1}$ CIRCE (Conservation, Information and Research on Cetaceans), C/Cabeza de Manzaneda 3, Algeciras-Pelayo, 11390 Cadiz, \\ Spain \\ ${ }^{2}$ GEMA (Grupo de Ecología Marina Aplicada), Estación Biológica de Doñana, CSIC, C/Americo Vespucio, s/n, \\ 41092 Isla de la Cartuja, Sevilla, Spain \\ ${ }^{3}$ Alnilam Research and Conservation, Cándamo 116, 28240 Hoyo de Manzanares, Madrid, Spain
}

\begin{abstract}
Long-finned pilot whales Globicephala melas are a commonly encountered species in the Mediterranean Sea. In 2006-2007, an outbreak of the dolphin morbillivirus in the Western Mediterranean resulted in increased mortality of this species. The aim of this study was to determine whether survival rates differed between clusters of Spanish Mediterranean pilot whales, and how the epizootic influenced these survival rates. Photo-identification surveys were conducted between 1992 and 2009. Association indices were used to define clusters of individuals that associate with each other more frequently than with others. Based on a Cormack-JollySeber survival rate model, apparent survival rate estimates varied from 0.821 to 0.995 over 11 clusters for the 1992-2009 period. When the effect of the morbillivirus outbreak was modeled, 3 clusters with distinctly lower survival rates from previous models presented lower estimates after the outbreak (survival rate dropped from 0.919 [95\% CI: $0.854-0.956$ ] to 0.547 [95\% CI: $0.185-0.866]$ ), suggesting a negative influence of the epizootic or other unknown additive factors on certain clusters. This information is critical for the conservation of long-finned pilot whales, since they are listed as 'data deficient' in the Mediterranean Sea by the IUCN and as 'vulnerable' in the Spanish National Catalogue of Endangered Species.
\end{abstract}

KEY WORDS: Long-finned pilot whale $\cdot$ Survival rate · Cormack-Jolly-Seber · Morbillivirus · Mediterranean Sea $\cdot$ Photo-identification

Resale or republication not permitted without written consent of the publisher

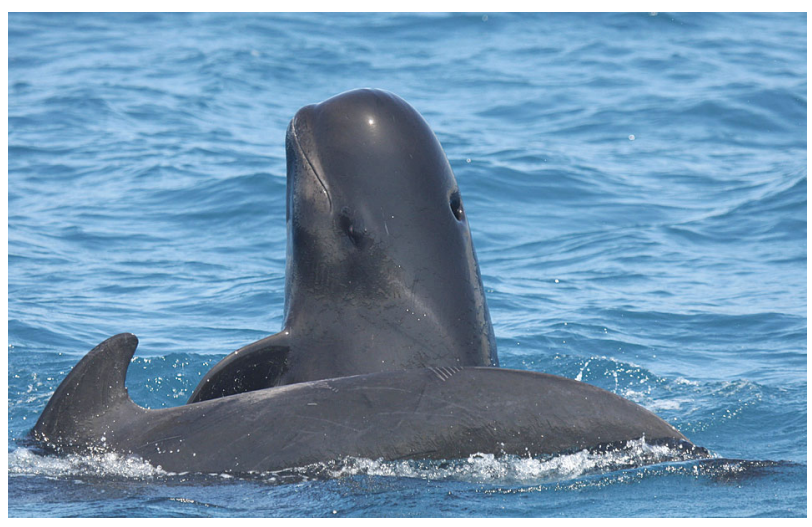

Diseases can severely decrease survival rates of long-finned pilot whales Globicephala melas.

Image: Pauline Gauffier

\section{INTRODUCTION}

Diseases play an important role in the survival of endangered species (Daszak et al. 2000, Cleaveland et al. 2001) and may have a devastating effect on small populations. Three examples are the canine distemper that eradicated the black-footed ferret (Williams et al. 1988), chytrid fungi and iridoviruses that may play a role in declining amphibian populations worldwide (Daszak et al. 1999), and the effect of vacuolar myelinopathy in bald eagles (Fischer et al. 2002). By decreasing survival or reproduction of individuals, infections may influence the abundance or 
population density of their host. The effects of disease outbreaks are difficult to evaluate, especially in marine species, which are challenging to sample for direct population dynamics analysis. To our knowledge no study has ever evaluated the effect of an epizootic on the survival rate of a cetacean population. In 19901991, an outbreak of the dolphin morbillivirus resulted in thousands of striped dolphins Stenella coeruleoalba stranding dead on the coast of the Mediterranean Sea (Aguilar \& Raga 1993, Van Bressem et al. 1993, Fernández et al. 2008, Raga et al. 2008). The effects of this epizootic could not be evaluated, and nothing is known about how it influenced survival rates of the Mediterranean population of this species. In 20062007, a second outbreak affected not only striped dolphins (Raga et al. 2008) but also long-finned pilot whales Globicephala melas (Fernández et al. 2008). The epizootic lasted from October 2006 to April 2007, during which 27 long-finned pilot whales were found stranded on the south coast of Spain, beginning with 10 animals stranding in the Strait of Gibraltar, expanding north-east along the coast of the Alboran Sea and ending at the Balearic Islands (Fernández et al. 2008). This number is very high, considering the average stranding rate of long-finned pilot whales in southern Spain (from the Strait of Gibraltar to Murcia) of 7.55 individuals per year before the epizootic (Fernández et al. 2008). All but 2 of the stranded whales were either adults or sub-adults, and necropsy performed on 9 individuals showed changes in the lymph nodes, brain or lungs (Fernández et al. 2008). In addition, 6 individuals were assessed for morbillivirus, and all tested positive (Fernández et al. 2008). This was the first reported morbillivirus outbreak in long-finned pilot whales, despite the previously noted presence of antibodies in this species (Duignan et al. 1995). The virus found in the stranded pilot whales was nearly identical to the strain present in the striped dolphins, suggesting that interspecies transmission of the virus is possible (Fernández et al. 2008). The morbillivirus is transmitted through mucus membranes (Black 1991), and pilot whales may be vectors of the virus for other cetaceans (Duignan et al. 1995). Different factors including level of pollution, climate change, anthropogenic activity and prey availability may influence the prevalence and severity of the infection by decreasing immune system function in the host (van Bressem et al. 2009).

Long-finned pilot whales are common throughout the Mediterranean Sea (Cañadas et al. 2002, 2005, Mangion \& Gannier 2002, Gannier 2005, de Stephanis et al. 2008a). The pelagic areas of the Alboran Sea as well as the Strait of Gibraltar are preferred habi- tats (Cañadas \& Sagarminaga 2000, Cañadas et al. 2005, de Stephanis et al. 2008a) where the whales are present throughout most of the year (Cañadas \& Sagarminaga 2000), suggesting a resident population. The regions with the highest encounter rate of groups were the Granada-Almeria area as well as the Strait of Gibraltar and the Gulf of Vera (Cañadas et al. 2005, de Stephanis et al. 2008a). Sightings of longfinned pilot whales in these 3 areas showed a discontinuous distribution (Cañadas et al. 2005, de Stephanis et al. 2008a) and may indicate the presence of separate clans of long-finned pilot whales within the Alboran Sea population (de Stephanis et al. 2008b,c).

In the Faroe Islands, long-finned pilot whales form strict matrilineal groups similar to the ones found in resident killer whales (Amos et al. 1993, Fullard 2000). A single population is formed by several clans, which consist of pods created by related matrilineal units. In this hierarchical social system, group philopatry of both males and females is observed, and groups are very stable (Mussi et al. 2000, Ottensmeyer \& Whitehead 2003, de Stephanis et al. 2008b). As a result, all members of the clan are related to each other (Amos et al. 1993) and distinct genetic differences between clans are observed (Andersen 1993).

Long-finned pilot whales are classified as 'data deficient' on the IUCN red list of endangered species, both worldwide and at the Mediterranean subpopulation level (Taylor et al. 2008, Cañadas 2012); however, in Spain they are a high priority species, and the Mediterranean population was classified as 'vulnerable' in 2011 after the morbillivirus epizootic (Real Decreto 139/2011; www.boe.es/boe/dias/2011/ 02/23/pdfs/BOE-A-2011-3582.pdf [in Spanish]).

The aim of this study was to estimate the shortterm population effects of the morbillivirus epizootic on a wild cetacean population and to evaluate whether the whole population was affected in the same way. We used natural permanent markings (Hammond 1986, Bigg et al. 1990, Shane \& McSweeney 1990) of long-finned pilot whales to determine the number of clusters of this species within the Alboran Sea population and to estimate survival rates for each cluster.

\section{MATERIALS AND METHODS}

\section{Survey area}

The Alboran Sea (Fig. 1) is located in the western Mediterranean, surrounded by Algeria, Morocco, Spain and Gibraltar (UK). Due to differences in shelf 
edge slope, depth, presence of ridges, volcanic activity, and proximity to fronts and currents (Parrilla \& Kinder 1987), the Alboran Sea is an extremely productive and diversified region (Rodríguez 1982, Rubín et al. 1992). In addition, fertilization of the water through up-welling of nutrients results in high abundance of zooplankton (Rubín et al. 1992, Rubín 1994, 1997), providing a food base for many species of predatory fish and cetaceans. As the Alboran Sea is separated from the Atlantic Ocean only by the Strait of Gibraltar, it is an obligatory migration route for species traveling from the Atlantic to the Mediterranean. As a result, the Alboran Sea is rich in cetacean species (Cañadas et al. 2002, 2005) and a crucial feeding and breeding ground for these animals (Cañadas \& Sagarminaga 2000, Cañadas et al. 2005, Cañadas 2006).

\section{Data collection}

Surveys were carried out in the Alboran Sea as well as in the Gulf of Vera on the north side of the basin along the Spanish coast (Fig. 1) between July 1992 and August 2009. A majority of the surveys was carried out on ALNITAK's research vessel Toftevaag, an $18 \mathrm{~m}$ auxiliary powered sailing yacht with 2 observation platforms 12 and $2.5 \mathrm{~m}$ above sea level; from these platforms, trained observers used $7 \times 50 \mathrm{~mm}$ binoculars to search for whales (for details see Cañadas \& Sagarminaga 2000, Cañadas et al. 2002). At sea, each sighted group of long-finned pilot whales was approached and photographs of the dorsal fins (both left and right side) were taken. Due to the extended length of the study, different cameras were used, and all film cameras were replaced by digital ones in 2004. A sighting was defined as the observation of a group of long-finned pilot whales showing similar behavior with individuals no more than $1000 \mathrm{~m}$ away from each other. Surveys ended when sea state reached 3 Douglas. Transects were recorded using the International Fund for Animal Welfare's (IFAW) Logger 2000 free software (http://logger-2000.software. informer.com/).

\section{Data analysis}

Slides taken before 2004 were scanned and uploaded onto a computer enabling the analysis of each photograph in ACDsee Pro 5 under the same protocol, following Verborgh et al. (2009). For every fin in a photograph, the frame number, sighting number, identification code (ID), and angle (every $30^{\circ}$, with $0^{\circ}$ defined as the animal facing the camera) were recorded. Based on the angle, focus and fin exposure, photos were assigned a general quality rank (Q) from 0 (worst quality) to 2 (best quality: entire fin exposed, with a perfect focus and a perpendicular angle); only good quality (Q1 and Q2) photos were taken into consideration to decrease the possibility of misidentification. The fin was then compared to individuals in the catalogue in order to find a match. If a match was not found, a new ID was given and the individual was

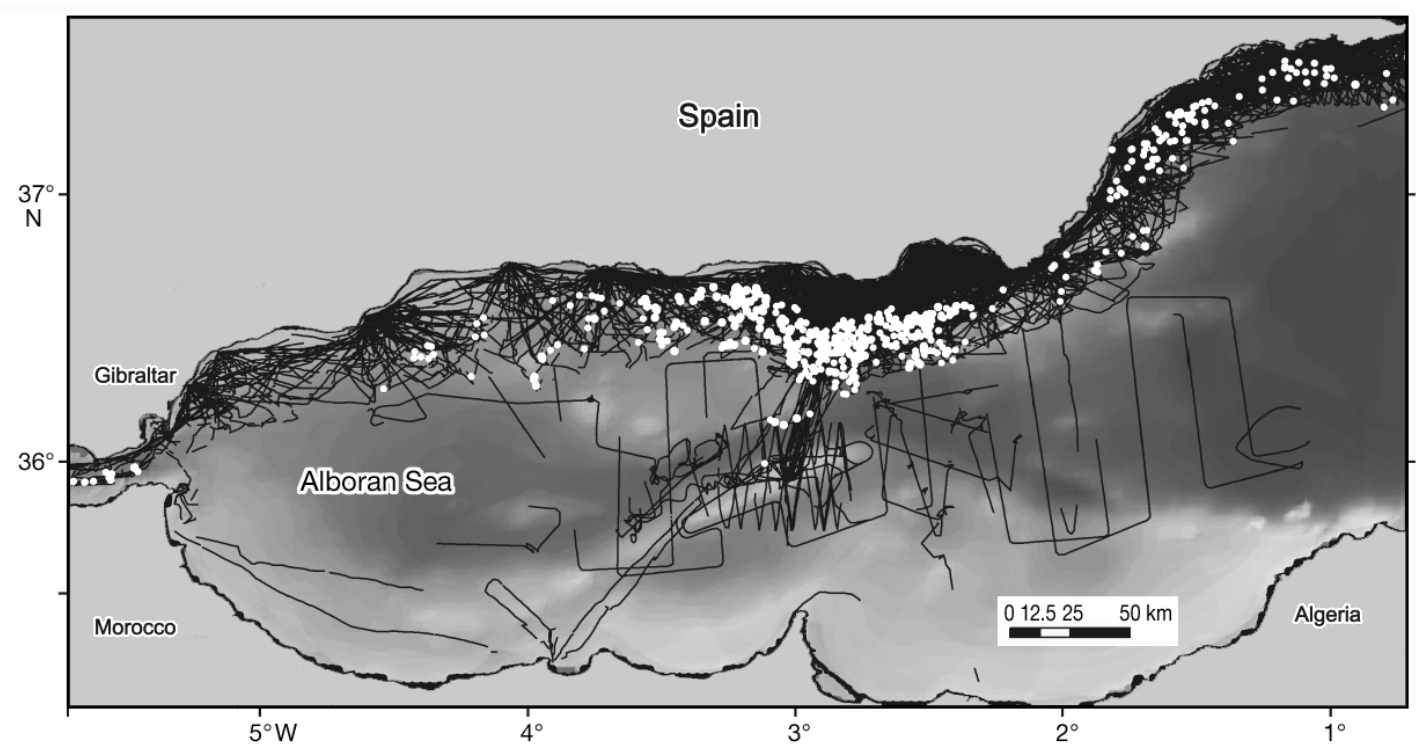

Fig. 1. Surveys (black lines) and sightings (white dots) of long-finned pilot whales Globicephala melas carried out between July 1992 and August 2009 in Spanish Mediterranean waters. Gray shading shows sea bathymetry $($ dark = deep) 
added to the catalogue. Each animal was assigned a marking level (M) from 1 to 3 (M1: lightly marked, M2: moderately marked, M3: well marked) (Verborgh et al. 2009). Only nicks and notches were considered markings; therefore, individuals presenting only scarring were defined as 'unmarked' and not used in the analysis. Saddle patches of long-finned pilot whales are also permanent features (Auger-Méthé \& Whitehead 2007) and were used as a confirmation of the identity of animals with an M1 rank. As the main focus of the study was to look for a possible effect of the morbillivirus epizootic on the population, only animals first sighted before the initial outbreak in 2006 were used for all analyses.

\section{Defining clusters}

To define clusters within the population, the compiled version of SOCPROG 2.4 (Whitehead 2009) was used. Individuals seen together at least once within a sighting were considered associated for the sampling period (day), and data were restricted to pilot whales seen on a minimum of 2 sightings. First, the variation of the social system was measured by obtaining the coefficient of variation of true association indexes (social differentiation), which is an estimate of whether the data reflect a homogeneous society or a socially differentiated population (Whitehead 2008b). The strength of the behavioral relationships between dyads was estimated using a half-weight association index $\alpha_{\mathrm{AB}}$ (Ginsberg \& Young 1992):

$$
\alpha_{\mathrm{AB}}=\frac{x}{x+y_{\mathrm{AB}}+\frac{1}{2}\left(y_{\mathrm{A}}+y_{\mathrm{B}}\right)}
$$

where A and B are individuals in the association, $x$ is the number of sampling periods with $\mathrm{A}$ and $\mathrm{B}$ observed associated, $y_{\mathrm{A}}$ is the sampling period with only A identified, $y_{\mathrm{B}}$ the sampling period with only $\mathrm{B}$ identified and $y_{\mathrm{AB}}$ is the number of sampling periods with $\mathrm{A}$ and $\mathrm{B}$ identified but not associated together.

A cluster analysis was performed to visualize the associations between individuals and relative rates of interaction between groups. Then, the cophenetic correlation coefficient was calculated to ensure that the dendrogram reflects the matrix of interaction rates. The association index corresponding to the maximum modularity was used to define community division by clusters (Whitehead 2008b, 2009).

To determine temporal changes in the cluster structure, we used the standardized lagged association rate (SLAR) (Whitehead 1995, 1997) given by the equation:

$$
\hat{g}(\tau)=\frac{\sum_{\mathrm{A}} \sum_{t} w(\mathrm{~A}, t, \tau)}{\sum_{\mathrm{A}} \sum_{t} N(\mathrm{~A}, t) \cdot N(\mathrm{~A}, t+\tau)}
$$

where $w(\mathrm{~A}, t, \tau)$ is the number of associates that were seen with individual $\mathrm{A}$ at both time $t$ and time $t+\tau$, and $N(\mathrm{~A}, t)$ is the number of associates seen with individual A at time $t$. The SLAR is the average probability that a pair of individuals recorded together at time zero will be together again at subsequent time periods. The SLAR was jackknifed (Efron \& Gong 1983) and plotted against the time lag using a moving average method. The standardized null association rate (SNAR) (expected if individuals were associating at random, and calculated as $g(\tau)=1 /(P-1)$, where $P$ is the marked population; Whitehead 1995) was compared to our results, to ensure that they were not random.

After bootstrapping the data, tie strengths (ts, sum of the association indices) (Barrat et al. 2004, Whitehead 2009) were compared between clusters to evaluate gregariousness and create a base for grouping clusters when modeling survival rates.

\section{Estimation of survival rates for each cluster}

From 1992 to 2009, all the sightings from June to November were grouped together to form 1 capture occasion per year. Individuals were attributed to different groups based on the clusters defined by the cluster analysis (hereafter referred to as clusters). Goodness-of-fit tests were performed in the program U-CARE (Choquet et al. 2009) to detect problems of transience or trap-dependence in the dataset. Annual capture-recapture data were analyzed with Cormack-Jolly-Seber (CJS) models (Cormack 1964, Jolly 1965, Seber 1965) in the program MARK 7.1 (White \& Burnham 1999) in order to estimate annual survival and recapture probability. This model stands on the following assumptions (Pollock et al. 1990): (1) All individuals in a group have the same capture probability $p$ at occasion $t_{i}(2)$ all individuals in a group have the same survival probability $\varphi$ between occasions $t$ and $t+1$; (3) marks are not lost; (4) capture occasions are short in time compared to the interval between two successive occasions. An effort was made to photograph all sighted whales, irrespective of their size or marking level, to ensure that all the individuals have the same probability of capture (Assumption 1). All the individuals used in this study were adults, so they likely had a similar probability to survive from one year to the next (Assumption 2). Furthermore, this assumption was met by grouping individuals with higher affinity in clusters. Assump- 
tions 1 and 2 were also verified by the goodness-of-fit tests which confirmed no trap-dependence or transience. Identifying marks were not lost over the study period since individuals observed in 1992 still had the same marks in 2009, therefore meeting Assumption 3. Finally, Assumption 4 was met since all the summer months (June to November) were grouped together to form one capture occasion per year, and the interval between occasions was represented by the rest of the year.

We considered various models to test for differences and similarities of survival rates between clusters, and for the possible effects of the morbillivirus outbreak of 2006-2007. We started with the model $\varphi_{t^{*} c} p_{t^{*} c}$ (Table 1, Model 20) where survival rate $(\varphi)$ and capture probability $(p)$ varied through time $(t)$ and between clusters $(c)$. We then fitted more parsimonious models by constraining subsequent parameters to be constant in time (.) or to be the same for certain clusters (numerical subscripts stand for the cluster numbers to which a given constraint was applied to, an 'all' subscript indicates that all clusters were modeled as 1 group, and ' + ' denotes given clus- ters being modeled as 1 group). Modeling step (MS) refers to the order in which the models were tested. After fitting the best model for $p$ (Table 1, MS I), we found the best models for $\varphi$ (Table 1, MS II). Additionally, within capture probability, the effect of using slides or digital pictures ( $\left.p_{\text {camera }}\right)$ was tested (Table 1, MS III). Once a general model for $\varphi$ was obtained, we explored those grouping clusters with highest tie strengths (ts $\geq 0.55$ ) (Table $1, \mathrm{MS}$ IV).

We then investigated the possible effects of the morbillivirus outbreak (Table 1, MS V). Three types of possible effects of the outbreak were tested: a change in survival rates from the year of the morbillivirus epizootic until $2009\left(\varphi_{\mathrm{MV} 3}\right)$, a change in survival in the year of the epizootic in addition to a postepizootic effect in the 2 following years $\left(\varphi_{\mathrm{MV}+\text { post }}\right)$ and a delayed ('late') effect of the morbillivirus on the survival rate, i.e. changed survival from 2007 to 2009 $\left(\varphi_{\text {MVlate }}\right)$.

Next, we evaluated models looking at differences in survival rates before and after the morbillivirus epizootic for clusters with low overall survival rates (Table 1, MS VI). We also inspected whether the mor-

Table 1. Model selection for estimating apparent survival rates $(\varphi)$ of long-finned pilot whales Globicephala melas between 1992 and 2009 in Spanish Mediterranean waters. The most parsimonious model has the lowest corrected Akaike's information criterion $\left(\mathrm{AIC}_{\mathrm{c}}\right.$ ) value. $\Delta \mathrm{AIC}_{\mathrm{c}}$ : difference of $\mathrm{AIC}_{\mathrm{c}}$ value from best suited model (bold); NP: number of parameters; MS: modeling step. AIC $_{c}$ weights, model likelihood and deviance are as defined by Cooch \& White (2012). Model notations - $p$ : capture probability; $t^{*} c$ : time and group dependent; $t$ : time dependent; ' '? constant through time; all: all clusters are modeled as 1 group ; +: given clusters are modeled as 1 group (based on tie strength value); camera: effect of using slides or digital pictures; photo effort: standardized photographic effort used as covariate; MV3: morbillivirus effect from 2007 to 2009; MV+post: morbillivirus effect in 2007 and post-epizootic effect from 2008 to 2009; MVlate: morbillivirus effect from 2007 to 2009

\begin{tabular}{|c|c|c|c|c|c|c|c|c|}
\hline No. & Model & $\mathrm{AIC}_{\mathrm{C}}$ & $\Delta \mathrm{AIC}_{\mathrm{c}}$ & $\begin{array}{c}\mathrm{AIC}_{\mathrm{c}} \\
\text { weights }\end{array}$ & $\begin{array}{c}\text { Model } \\
\text { likelihood }\end{array}$ & NP & Deviance & MS \\
\hline 1 & $\left\{\varphi_{\text {MV3 }(4+10+11)} \varphi_{\cdot(1,2,3,5+6,7+8+9)} p_{t(\text { all })}\right\}$ & 1476.80 & $\mathbf{0}$ & 0.547 & 1 & 24 & 1040.65 & VII \\
\hline 2 & $\left\{\varphi_{(1,2,3,4,5+6,7+8+9,10,11)} p_{t(\text { all })}\right\}$ & 1479.30 & 2.506 & 0.156 & 0.286 & 25 & 1040.91 & IV \\
\hline 3 & $\left\{\varphi_{(1,2,3,4,5,6,7,8+9,10,11)} p_{t(\mathrm{alll})}\right\}$ & 1481.01 & 4.215 & 0.067 & 0.122 & 27 & 1038.10 & IV \\
\hline 4 & $\left\{\varphi \cdot p_{t(\mathrm{all})}\right\}$ & 1481.16 & 4.367 & 0.062 & 0.113 & 28 & 1035.98 & II \\
\hline 5 & $\left\{\varphi_{\text {MV3(4,10,11) }} \varphi_{\cdot(1,2,3,5+6,7+8+9)} p_{t(\text { all })}\right\}$ & 1481.23 & 4.428 & 0.06 & 0.109 & 28 & 1036.04 & VI \\
\hline 6 & $\left\{\varphi \cdot(1,2,3,4,5,6,7+8+9,10,11) p_{t(\mathrm{alll})}\right\}$ & 1481.50 & 4.708 & 0.052 & 0.095 & 26 & 1040.86 & IV \\
\hline 7 & $\left\{\varphi_{\mathrm{MV}+\operatorname{post}(4,10,11)} \varphi \cdot(1,2,3,5+6,7+8+9) p_{t(\mathrm{all})}\right\}$ & 1482.71 & 5.914 & 0.028 & 0.052 & 29 & 1035.24 & VI \\
\hline 8 & $\left\{\varphi \cdot(1,2,3,4,5,6,7+9,8,10,11) p_{t(\text { all })}\right\}$ & 1483.00 & 6.200 & 0.025 & 0.045 & 27 & 1040.08 & IV \\
\hline 9 & $\left\{\varphi_{\text {MVlate }(4,10,11)} \varphi \cdot(1,2,3,5+6,7+8+9) p_{t(\text { all })}\right\}$ & 1485.00 & 82.010 & 0.009 & 0.017 & 28 & 1098.09 & VI \\
\hline 10 & $\left\{\varphi_{\mathrm{MV} 3} p_{t(\mathrm{all})}\right\}$ & 1487.17 & 10.370 & 0.003 & 0.006 & 39 & 1016.21 & V \\
\hline 11 & $\left\{\varphi_{\text {MVlate }} p_{t(\text { all })}\right\}$ & 1491.99 & 15.197 & 0 & 0.001 & 39 & 1021.03 & $\mathrm{~V}$ \\
\hline 12 & $\left\{\varphi_{\mathrm{MV}+\text { post }} p_{t(\text { all })}\right\}$ & 1493.78 & 16.984 & 0 & 0 & 47 & 1003.19 & $\mathrm{~V}$ \\
\hline 13 & $\left\{\varphi \cdot(\right.$ all $\left.) p_{t(\text { all })}\right\}$ & 1497.41 & 20.614 & 0 & 0 & 18 & 1074.50 & II \\
\hline 14 & $\left\{\varphi_{t \text { (all })} p_{t(\text { all })}\right\}$ & 1519.55 & 42.756 & 0 & 0 & 33 & 1062.82 & II \\
\hline 15 & $\left\{\varphi_{\text {MV3(4+10+11) }} \varphi_{(1,2,3,5+6,7+8+9)} p_{\text {photo effort }}\right\}$ & 1563.12 & 86.326 & 0 & 0 & 8 & 1161.48 & VIII \\
\hline 16 & $\left\{\varphi \cdot p_{\text {camera }}\right\}$ & 1576.10 & 99.306 & 0 & 0 & 13 & 1163.95 & III \\
\hline 17 & $\left\{\varphi_{t^{*} c} p_{t(\mathrm{alll})}\right\}$ & 1970.31 & 493.513 & 0 & 0 & 185 & 952.325 & I \\
\hline 18 & $\left\{\varphi_{t^{*} C} p_{\cdot(\text { (all })}\right\}$ & 2042.75 & 565.950 & 0 & 0 & 170 & 1107.54 & I \\
\hline 19 & $\left\{\varphi_{t^{*} c} p.\right\}$ & 2082.82 & 606.020 & 0 & 0 & 180 & 1093.46 & I \\
\hline 20 & $\left\{\varphi_{t^{*} c} p_{t^{*} c}\right\}$ & 5685.98 & 4209.187 & 0 & 0 & 374 & 710.21 & I \\
\hline
\end{tabular}


billivirus effect was the same or different for these clusters (Table 1, MS VII). Akaike's information criterion corrected for small sample size $\left(\mathrm{AIC}_{\mathrm{c} i}\right.$ Sugiura 1978, Hurvich \& Tsai 1989) was used to compare models and select the best one.

After obtaining a final model, the influence of photographic effort ( $p_{\text {photo effort }}$ ) on capture probability was tested using the standardized number of fin images $(Z)$ analyzed per year (Table 1, MS VIII). We standardized the data applying the following equation:

$$
Z=\frac{x-\mu}{\sigma}
$$

where $x$ is the number of fins in a given year, $\mu$ is the mean number of images per year and $\sigma$ is the standard deviation.

\section{RESULTS}

\section{Surveys}

Transects covered a total of $83161 \mathrm{~km}$ (Fig. 1) and resulted in 259 sightings of long-finned pilot whales for which photo identification data could be taken. The sightings were recorded on $105 \mathrm{~d}$. A total of 7271 photographs showing 10028 dorsal fins were analyzed, out of which 5591 (56\%) were identified. Photographic effort and the number of fins analyzed increased with time, most rapidly from 2006 onwards (Fig. 2). Q2 and Q1 images constituted 8 and $78 \%$ of the total number of analyzed photographs, respectively. The photo-ID catalogue consisted of 764 individuals with $61.5 \%$ being lightly marked (M1) and $38.5 \%$ moderately or well marked (M2, M3).

\section{Defining clusters}

Social differentiation was estimated as 1.710 (SE = 0.268 ), indicating a socially well differentiated population (Whitehead 2008a). The cluster diagram (with cophenetic correlation coefficient $=0.8$ ) shows that most individuals were sighted with preferred companions. Community division by modularity identified 11 clusters (modularity $=0.55$, association index $=0.03$ ) (Fig. 3) with a mean size of 16.5 (range: 3-32) marked individuals per cluster.

The SLAR stayed higher than the SNAR (null association rate $=0.005$ ), showing that clusters would be stable for the whole study period. Tie strengths were strongest ( $\mathrm{ts} \geq 0.55$ ) between Clusters 5 and 6 ( $\mathrm{ts}_{5,6}=$ 0.55), Clusters 9 and 7 ( ts $_{9,7}=0.62$ ) and Clusters 9 and $8\left(\mathrm{ts}_{9,8}=0.62\right)$.

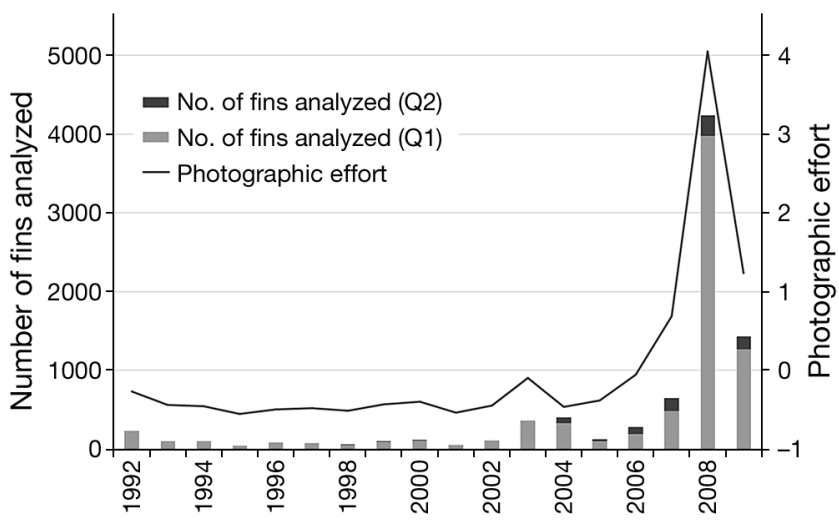

Fig. 2. Number of Globicephala melas fins analyzed and photographic effort per year (see Eq. 3). Photo quality rank - Q1: medium quality, fin partially or fully exposed, with visible nicks, angle $240^{\circ}$ to $300^{\circ}$ or $60^{\circ}$ to $120^{\circ}$ between fin and camera; Q2: best quality, entire fin exposed, with a perfect focus and a perpendicular angle

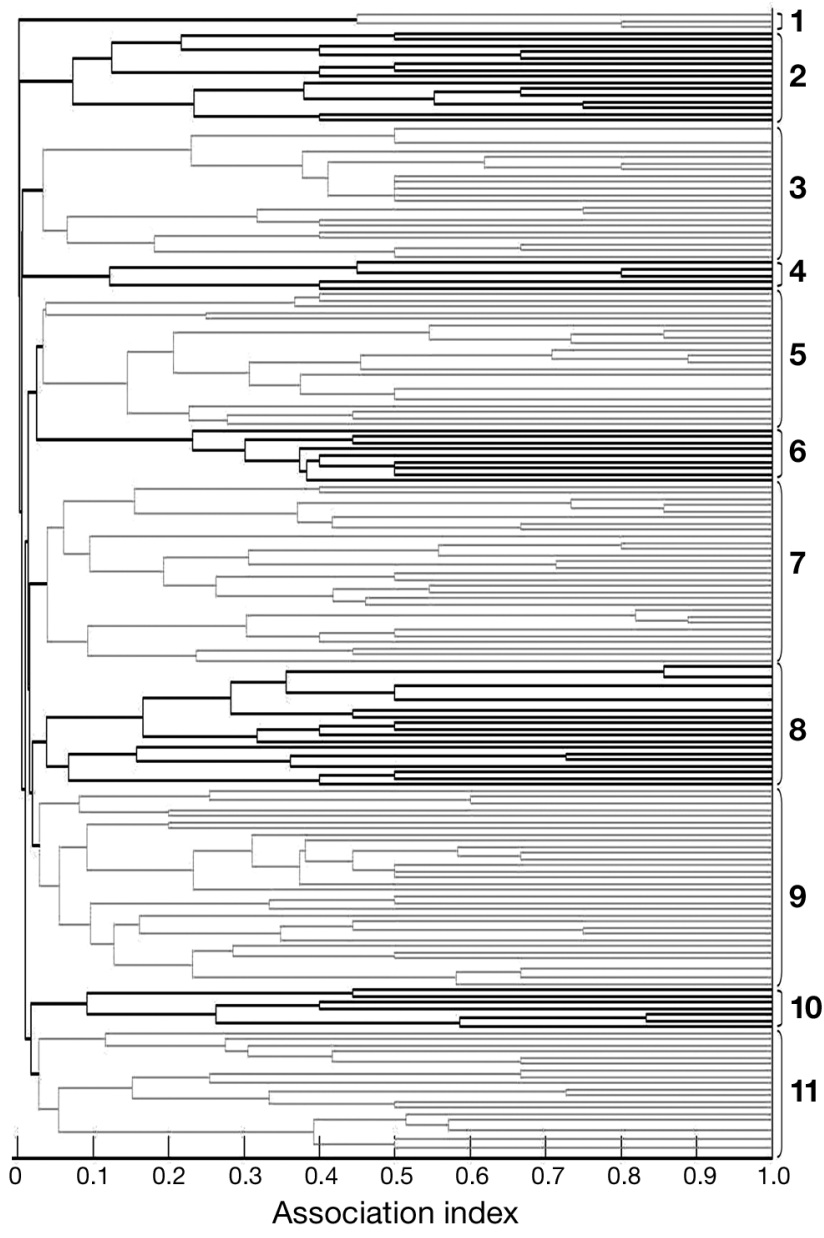

Fig. 3. Average linkage cluster analyses of association (halfweight association index) between individuals seen on $>1$ d for long-finned pilot whales Globicephala melas in Spanish Mediterranean waters. Numbers on the right indicate cluster numbers 


\section{Estimation of survival rates of clusters}

The global goodness of fit test was not significant $\left(\chi^{2}=69.7591, \mathrm{df}=137, \mathrm{p}=1.000\right)$ showing no problems of either trap-dependence or transience in any of the clusters. We started with the model $\left\{\varphi_{t}{ }^{*} p_{t} p{ }^{\circ}\right\}$ (Model 20) in the first modeling step (Table 1, MS I). Capture probability modeled to vary in time and to be the same for all clusters proved to be the best fit for our data (Model 17). The type of cameras used (Model 16) and the photographic effort (Model 15) did not influence the capture probability $p$. From models investigating basic survival rates (Table 1, MS II), Model 4 proved to be the best fit. Having obtained a basic model, we explored whether survival rates were similar for clusters with ts $\geq 0.55$ (Table 1, MS IV). Survival rates of the following clusters were grouped together: 8+9 (Model 3), 7+8+9 (Model 6), 7+9 (Model 8), 5+6 and 7+8+9 (Model 2) and Model 2 had the lowest $\mathrm{AIC}_{\mathrm{c}}$ value (1479.30).

Preliminary survival rates for each cluster or group of clusters for the whole study period estimated by Model 2 ranged from 0.821 (95\% CI: 0.628-0.992; Cluster 10) to 0.995 (95\% CI: 0.951-0.999; Cluster $7+8+9$ ) (Fig. 4). The survival rate could not be estimated for Cluster 2. Clusters 4, 10 and 11 presented the lowest survival rates $(0.891,95 \%$ CI: $0.709-0.999$; $0.821,95 \%$ CI: $0.628-0.9926$ and $0.918,95 \%$ CI: 0.853-0.956, respectively), although their $95 \%$ CI overlapped with other clusters (Fig. 4).

Next, the effects of the morbillivirus outbreak (Table 1, MS V) were best estimated when taking into account the 3 yr epizootic effect (MV3) (Table 1, Model 10), showing a lower survival rate after than before the epizootic. We then investigated the possibility that there was an effect of the morbillivirus only for the 3 clusters $(4,10$ and 11$)$ that presented the lowest survival rate estimates in Model 2. We therefore modeled a morbillivirus effect for only these 3 clusters separately (Table 1, MS VI). The MV3 effect, with the lower $\mathrm{AIC}_{\mathrm{c}}$ of MS VI, was then modeled for the same 3 clusters grouped together (Table 1, MS VII).

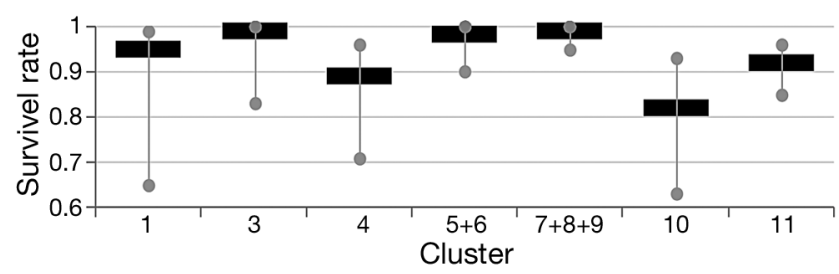

Fig. 4. Survival rates for each cluster or group of clusters of long-finned pilot whales Globicephala melas for 1992-2009 estimated by the basic model (Model 2, see Table 1) with $95 \%$ CI. Cluster 2 was not estimated

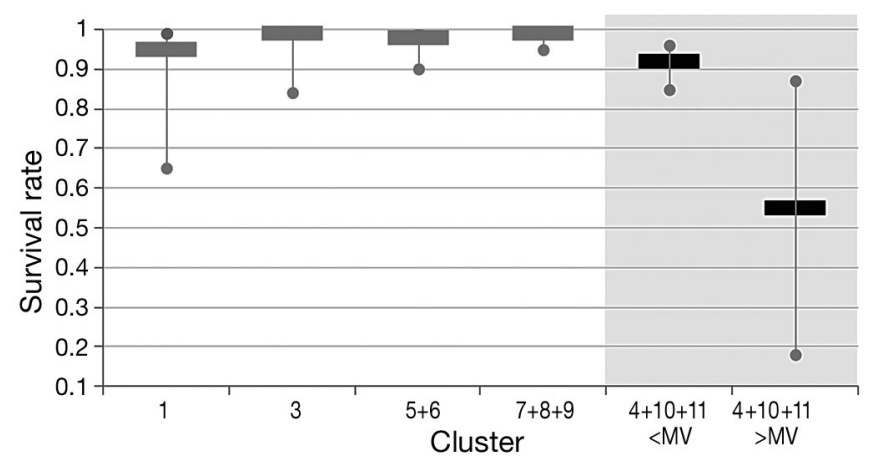

Fig. 5. Survival rates for each cluster or group of clusters for 1992-2009 estimated by the best model (Model 1, see Table 1) with $95 \%$ CI. <MV: before epizootic, >MV: after epizootic. Cluster 2 was not estimated

The best model (Table 1, Model 1) estimated that the morbillivirus outbreak had the same effect on Clusters 4, 10 and 11 but did not detect any morbillivirus effect for any of the other clusters or groups of clusters. Annual survival rate estimates for the group of Clusters 4, 10 and 11 decreased from 0.919 (95\% CI: $0.854-0.956)$ before 2006 to 0.547 (95\% CI: 0.185-0.866) after the morbillivirus outbreak (Fig. 5). For the other clusters or groups of clusters, the annual survival rates were estimated to be constant over the study period and ranged from 0.947 (95\% CI: $0.645-0.994)$ for Cluster 1 to 0.995 (95\% CI: 0.952-0.999) for Cluster 7+8+9 (Fig. 5). Again, the survival rate could not be estimated for Cluster 2 .

\section{DISCUSSION}

To our knowledge, this is the first published study evaluating the effect of a morbillivirus epizootic on the survival rates of a cetacean population. The results showed differences within the population, as not all clusters were affected by the outbreak in the same way. For some clusters, no morbillivirus effect was detected over the study period, while for Clusters 4, 10 and 11 the survival rate strongly decreased after the epizootic. The decrease in survival rates observed only in these clusters may have been due to individual predispositions, such as impaired immune system functioning which may be influenced by external factors including pollution, climate change, anthropogenic activity and limited prey availability (Van Bressem et al. 2009); however, the exact causes remain unknown. We excluded the possibility of geographical separation being a factor, since members of Clusters 4, 10 and 11 were sighted near Almeria as well as in the Gulf of Vera. However, several clusters 
could use the same area but have a different diet, as seen in the social groups of the Strait of Gibraltar (de Stephanis et al. 2008c). Tie strengths were not high between these 3 clusters $\left(\operatorname{ts}_{4,10}=0, \mathrm{ts}_{4,11}=0.07\right.$ and $\mathrm{ts}_{10,11}=0.49$ ). Thus, pilot whales from different clusters that were not specifically associated with each other apparently had contact with the virus, confirming the possibility of transmission of the pathogen either by individuals that are immune to it or by another species inhabiting the same area (e.g. striped dolphins; Duignan et al. 1995, Fernández et al. 2008). However, only marked individuals were taken into account in our study, and certain bonds between groups may have been missed (i.e. unmarked or not photographed individuals from different clusters could have interacted with each other). A relatively low survival rate before the epizootic may have contributed to the strong effect of the morbillivirus outbreak on post-epizootic survival rate in these 3 clusters. Despite some overlap in the confidence intervals, pre-morbillivirus survival rate estimates were lower for Cluster $4+10+11(0.919$; Fig. 5) than for the rest of the clusters (0.947 for Cluster 1, which was the lowest survival rate estimate, most probably due to a very small group size of $n=3$, and 0.976 to 0.995 for the other clusters; Fig. 5).

The MV3 effect on the survival rates of Clusters 4, 10 and 11 estimated by Model 5 (Table 1) suggests that the low $\varphi$ values of the 3 individual clusters estimated by Model 2 (Table 1) were due to a decrease in survival rates after the epizootic. Our best model estimated a constant survival probability over the study period for Clusters 1, 3, 5+6 and 7+8+9, and detected a 3 yr morbillivirus effect for Cluster $4+10+11$. This model also detected differences in survival rates in clusters or groups of clusters before the epizootic (ranging from 0.919 to 0.995 ) and a decrease after the morbillivirus outbreak for Cluster 4+10+11 only, dropping from 0.919 before the epizootic to 0.547 after the outbreak (Fig. 5). This substantial decrease represents a 0.37 reduction in the survival rate and may have a severe impact on the 3 clusters. Photographic effort as well as the number of fins analyzed was much higher during the last $3 \mathrm{yr}$ of the study (2007 to 2009; Fig. 2); therefore, the observed decrease in survival rate was not due to a smaller data set or lower number of fins analyzed and identified following the epizootic.

This study did not aim to define the social structure of the long-finned pilot whale population in the Alboran Sea and Gulf of Vera. By creating clusters, we wanted to obtain groups of individuals that associate with each other more often than with others. These clusters may to some degree correspond to matrilineal groups observed for this species elsewhere (Fullard 2000, Ottensmeyer \& Whitehead 2003); however, no such assumptions were made in this study. The association index (and therefore the division of clusters) was based on maximum modularity (0.55), which was high enough to represent useful community divisions (Newman 2004, Whitehead 2009). The cophenetic correlation coefficient value of 0.8 ensured that the hierarchical averagelinkage cluster analysis of the association data reflects the matrix of interaction rates (Whitehead 2009). Additionally, the population's society proved to be well differentiated (social differentiation $>0.5$ ), therefore presenting weak as well as strong relationships between certain individuals (Whitehead 2009). The estimated SLAR stayed higher than the SNAR, indicating that individuals do not associate randomly and that long-term relationships exist (Whitehead 2009). Since only marked individuals were taken into consideration during the analysis, pilot whale newborns, calves and juveniles - which acquire nicks and notches with age (Ottensmeyer \& Whitehead 2003) - are underrepresented. Fernández et al. (2008) reported that the morbillivirus affected mostly adults, and it could be argued that our results are biased and overestimate the reduction in survival rates. However, the death of a lactating female would probably result in the death of her dependent calf. Moreover, pilot whales are organised in closed matrilineal units, similar to killer whales, for which the rearing of young animals and the interaction between the related individuals seem to play a major role in structure and dynamics (Amos et al. 1991, de Stephanis et al. 2008b,c). The deaths of killer whale mothers directly affect the survival of their offspring, even long after weaning (Foster et al. 2012). Therefore, these potential additive deaths caused indirectly by the epizootic likely compensate the bias.

Our analysis shows a severe impact of the morbillivirus on the survival rate of several clusters in the Alboran Sea and Gulf of Vera, which may have longterm effects on the population. However, for some clusters we could not detect any effect of the outbreak, therefore the overall population stock could recover following the epizootic. Further monitoring of the population is needed to assess long-term impacts resulting from the epizootic and to determine why certain clusters were affected differently by the outbreak. Additionally, a detailed social structure analysis should be done to examine to what degree matrilineal units correspond to clusters, and whether the death of key individuals (caused by the epizootic) had an effect on social structure of the population. 
Acknowledgements. The work was co-funded by ONR through the project 'Understanding the patterns and causes of variability in distribution, habitat use, abundance, survival and reproductive rates of three species of cetacean in the Alboran Sea' (Award N00014-11-1-0196), as well as by Earthwatch. This study was part of the project 'CETIDMED' coordinated by CIRCE, with the collaboration of Fundación Biodiversidad, Alnilam, ANSE and EBD-CSIC. We thank Alnitak for providing pictures for photo-identification of long-finned pilot whales between 1992 and 2009, and IFAW for providing the software Logger 2000. R. de S. was supported by the Spanish Ministry of Economy and Competitiveness, through the 'Severo Ochoa Programme for Centres of Excellence in R\&D\&I (SEV-2012-0262)', and the 'Subprograma Juan de la Cierva'.

\section{LITERATURE CITED}

Aguilar A, Raga JA (1993) The striped dolphin epizootic in the Mediterranean Sea. Ambio 22:524-528

Amos B, Barrett J, Dover GA (1991) Breeding system and social structure in the Faroese pilot whale as revealed by DNA fingerprinting. Rep Int Whal Comm Spec Issue 13: 255-268

Amos B, Bloch D, Desportes G, Majerus TM, Bancroft DR, Barrett JA, Dover GA (1993) A review of the molecular evidence relating to social organisation and breeding system in the long-finned pilot whale. Rep Int Whal Comm Spec Issue 14:209-217

Andersen LW (1993) Further studies on the population structure of the long-finned pilot whale, Globicephala melas, off the Faroe Islands. Rep Int Whal Comm Spec Issue 14: 219-231

Auger-Méthé M, Whitehead H (2007) The use of natural markings in studies of long-finned pilot whales (Globicephala melas). Mar Mamm Sci 23:77-93

Barrat A, Barthelemy M, Pastor-Satorras R, Vespignani A (2004) The architecture of complex weighted networks. Proc Natl Acad Sci USA 101:3747-3752

Bigg MA, Olesiuk PF, Ellis GM, Ford JKB, Balcomb KC (1990) Social organization and genealogy of resident killer whales (Orcinus orca) in the coastal waters of British Columbia and Washington State. Rep Int Whal Comm Spec Issue 12:383-405

Black FL (1991) Epidemiology of Paramyxoviridae. In: Kingsbury DW (ed) The paramyxoviruses. Springer, New York, NY, p 509-536

Cañadas A (2006) Towards conservation of dolphins in the Alborán Sea. PhD dissertation, Universidad Autónoma de Madrid

Cañadas A (2012) Globicephala melas (Mediterranean subpopulation). In: IUCN 2013. IUCN Red List of Threatened Species. Version 2013.1. www.iucnredlist.org (accessed on 22 August 2013)

> Cañadas A, Sagarminaga R (2000) The northeastern Alboran Sea, an important breeding and feeding ground for the long finned pilot whale (Globicephala melas) in the Mediterranean Sea. Mar Mamm Sci 16:513-529

> Cañadas A, Sagarminaga R, Garcia-Tiscar S (2002) Cetacean distribution related with depth and slope in the Mediterranean waters off southern Spain. Deep-Sea Res I 49:2053-2073

Cañadas A, Sagarminaga R, De Stephanis R, Urquiola E, Hammond PS (2005) Habitat preference modelling as a conservation tool: proposals for marine protected areas for cetaceans in southern Spanish waters. Aquat Conserv Mar Freshw Ecosyst 15:495-521

> Choquet R, Lebreton JD, Gimenez O, Reboulet AM, Pradel R (2009) U-CARE: Utilities for performing goodness of fit tests and manipulating CApture-REcapture data. Ecography 32:1071-1074

- Cleaveland S, Laurenson MK, Taylor LH (2001) Diseases of humans and their domestic mammals: pathogen characteristics, host range and the risk of emergence. Philos Trans R Soc Lond Ser B Biol Sci 356:991-999

Cooch E, White G (2012) Program MARK: a gentle introduction. www.phidot.org/software/mark/docs/book/

Cormack RM (1964) Estimates of survival from the sighting of marked animals. Biometrika 51:429-438

Daszak P, Berger L, Cunningham AA, Hyatt AD, Green DE, Speare R (1999) Emerging infectious diseases and amphibian population declines. Emerg Infect Dis 5:735-748

> Daszak P, Cunningham AA, Hyatt AD (2000) Emerging infectious diseases of wildlife-threats to biodiversity and human health. Science 287:443-449

de Stephanis R, Cornulier T, Verborgh P, Salazar Sierra J, Pérez Gimeno N, Guinet C (2008a) Summer spatial distribution of cetaceans in the Strait of Gibraltar in relation to the oceanographic context. Mar Ecol Prog Ser 353: $275-288$

de Stephanis R, Verborgh P, Pérez S, Esteban R, MinvielleSebastia L, Guinet C (2008b) Long-term social structure of long-finned pilot whales (Globicephala melas) in the Strait of Gibraltar. Acta Ethol 11:81-94

de Stephanis R, García-Tíscar S, Verborgh P, Esteban-Pavo R, Pérez S, Minvielle-Sebastia L, Guinet C (2008c) Diet of the social groups of long-finned pilot whales (Globicephala melas) in the Strait of Gibraltar. Mar Biol 154:603-612

Duignan PJ, House C, Geraci JR, Duffy N and others (1995) Morbillivirus infection in cetaceans of the western Atlantic. Vet Microbiol 44:241-249

Efron B, Gong G (1983) A leisurely look at the bootstrap, the jackknife, and cross-validation. Am Stat 37:36-48

> Fernández A, Esperón F, Herraéz P, de los Monteros AE and others (2008) Morbillivirus and pilot whale deaths, Mediterranean Sea. Emerg Infect Dis 14:792-794

Fischer JR, Lewis LA, Augspurger T, Rocke TE (2002) Avian vacuolar myelinopathy: A newly recognized fatal neurological disease of eagles, waterfowl and other birds. Trans N Am Wildl Nat Resour Conf 67:51-61

Foster EA, Franks DW, Mazzi S, Darden SK, Balcomb KC, Ford JK, Croft DP (2012) Adaptive prolonged post reproductive life span in killer whales. Science 337:1313

Fullard K (2000) Microsatellite analysis of long-finned pilot whales. PhD dissertation, Cambridge University

Gannier A (2005) Summer distribution and relative abundance of delphinids in the Mediterranean Sea. Rev Ecol Terre Vie 60:223-238

> Ginsberg JR, Young TP (1992) Measuring association between individuals or groups in behavioural studies. Anim Behav 44:377-379

Hammond PS (1986) Estimating the size of naturally marked whale populations using capture-recapture techniques. Rep Int Whaling Comm 8(Spec Issue):253-282

> Hurvich CM, Tsai L (1989) Regression and time series model selection in small samples. Biometrika 76:297-307

> Jolly GM (1965) Explicit estimates from capture-recapture data with both death and immigration-stochastic model. Biometrika 52:225-247 
Mangion P, Gannier A (2002) Improving the comparative distribution picture for Risso's dolphin and long-finned pilot whale in the Mediterranean Sea. Eur Res Cetaceans 16:68-72

Mussi B, Miragliuolo A, Lopez BD (2000) Social structure and male parental care in a long finned pilot whale (Globicephala melas) pod off Ventotene Island (Southern Tyrrhenian Sea, Italy). Eur Res Cetaceans 14:141-145

Newman ME (2004) Analysis of weighted networks. Phys Rev E Stat Nonlin Soft Matter Phys E70:056131, doi: 10.1103/PhysRevE.70.056131

Ottensmeyer CA, Whitehead H (2003) Behavioural evidence for social units in long-finned pilot whales. Can J Zool 81: 1327-1338

Parrilla G, Kinder TH (1987) Oceanografía física del mar de Alborán. Bol Inst Esp Oceanogr 4:133-165

Pollock KH, Nichols JD, Brownie C, Hines JE (1990) Statistical inference for capture-recapture experiments. Wildl Monogr 107:3-97

Raga JA, Banyard A, Domingo M, Corteyn M and others (2008) Dolphin morbillivirus epizootic resurgence, Mediterranean Sea. Emerg Infect Dis 14:471-473

Rodríguez J (1982) Oceanografía del mar Mediterráneo. Ediciones Pirámide, Madrid

Rubín JP (1994) El ictioplancton y el medio merino en los sectores norte y sur del mar de Alborán, en junio de 1992. Informe Técnico del Instituto Español de Oceanografía 146, Madrid

Rubín JP (1997) La influencia de los procesos ficso-quimicos y biológicos en la composición y distribución del ictioplancton estival en el mar de Alborán y estrecho de Gibraltar. Informe Técnico del Instituto Español de Oceanografía 24, Madrid

Rubín JP, Gil J, Ruiz J, Cortés MD, Jiménez-Gómez F, Parada M, Rodriguez J (1992) La distribución ictioplanctónica y su relación con parámetros físcos, químicos y biológicos en el sector norte del Mar de Alboran, en Julio de 1991 (Resultados de la Campana 'Ictio. Alboran 0791'). Informe Técnico del Instituto Español de Oceanografía 139, Madrid

Seber GA (1965) A note on the multiple-recapture census.

Editorial responsibility: Peter Corkeron,

Woods Hole, Massachusetts, USA
Biometrika 52:249-259

Shane SH, McSweeney D (1990) Using photo-identification to study pilot whale social organization. Rep Int Whal Comm Spec Issue 12:259-263

Sugiura N (1978) Further analysis of the data by Akaike's information criterion and the finite corrections. Commun Stat Theor Methods 7:13-26

Taylor BL, Baird R, Barlow J, Dawson SM and others (2008) Globicephala melas. In: IUCN 2012. IUCN Red List of Threatened Species. Version 2012.2. www.iucnredlist. org (accessed 7 March 2013)

- Van Bressem MF, Visser IKG, De Swart RL, Örvell C and others (1993) Dolphin morbillivirus infection in different parts of the Mediterranean Sea. Arch Virol 129:235-242

> Van Bressem MF, Raga JA, Di Guardo G, Jepson PD and others (2009) Emerging infectious diseases in cetaceans worldwide and the possible role of environmental stressors. Dis Aquat Org 86:143-157

> Verborgh P, De Stephanis R, Pérez S, Jaget Y, Barbraud C, Guinet $C$ (2009) Survival rate, abundance, and residency of long-finned pilot whales in the Strait of Gibraltar. Mar Mamm Sci 25:523-536

> White GC, Burnham KP (1999) Program MARK: survival estimation from populations of marked animals. Bird Study 46(S1):S120-S139

Whitehead H (1995) Investigating structure and temporal scale in social organizations using identified individuals. Behav Ecol 6:199-208

Whitehead H (1997) Analysing animal social structure. Anim Behav 53:1053-1067

Whitehead H (2008a) Precision and power in the analysis of social structure using associations. Anim Behav 75: 1093-1099

Whitehead H (2008b) Analyzing animal societies: quantitative methods for vertebrate social analysis. University of Chicago Press, Chicago, IL

Whitehead H (2009) SOCPROG programs: analyzing animal social structures. Behav Ecol Sociobiol 63:765-778

Williams ES, Thorne ET, Appel MJ, Belitsky DW (1988) Canine distemper in black-footed ferrets (Mustela nigripes) from Wyoming. J Wildl Dis 24(3):385-398

Submitted: November 25, 2013; Accepted: February 14, 2014 Proofs received from author(s): March 23, 2014 